\title{
Hydro-Energy Suitability of the Rivers Regarding Their Hydrological and Hydrogeological Characteristics
}

\author{
Bojan Đurin 1,*, Lucija Plantak ${ }^{2}$, Dragana Dogančić ${ }^{2}$, Nikola Kranjčić ${ }^{2}$ \\ 1 Department of Civil Engineering, University North, Varaždin, Croatia \\ 2 Faculty of Geotechnical Engineering, University of Zagreb, Varaždin, Croatia; lucija.plantak@gfv.unizg.hr \\ (L.P.); dragana.dogancic@gfv.unizg.hr (D.D.); nikola.kranjcic@gfv.unizg.hr (N.K.) \\ * Correspondence: bojan.durin@unin.hr; Tel.: +385-98-974-9716
}

\begin{abstract}
Production of the electric energy from the rivers by using the mini, as well as micro hydroelectric power plants is a very prospective solution, especially in the rural and isolated areas. Numerous waterways in Croatia and their hydrological and hydrogeological diversity present an opportunity, but also a challenge, for the construction of hydroelectric power plants. Due to the complexity of the water courses hydrology, as well as hydrogeological characteristics, it is very hard to determine an appropriate flow pattern (amount), which will be used as an input value for the sizing of hydroelectric power plants. Such analysis will be provided for real case studies in Croatia with special regard to present geological media - media with intergranular porosity (river Bednja), karstmedia (river Gornja Dobra), and flysch media (river Mirna). Taking into account different geological media increases the possibility of using the presented methodology on other locations in Croatia, as well in the world.
\end{abstract}

Keywords: water; energy; hydro power plant; river; flow

\section{Introduction}

Energy consumption is rapidly growing from year to year and the public and decision makers have realized the importance of switching to clean and renewable energy sources. Renewable power is thriving, as innovations reduce costs and for the first time the promise of a clean energy future looks achievable. Nowadays, the hydropower plants, including small-scale hydropower plants, produce the majority of the energy deemed as renewable. One cannot overlook both mini (from 100 $\mathrm{kW}$ to $500 \mathrm{~kW}$ ) and micro ( $5 \mathrm{~kW}$ to $100 \mathrm{~kW}$ ) hydropower plants which fit perfectly into the group of renewable energy sources. Unlike large-scale hydropower plants, mini and micro hydropower plants, if carefully planned and managed, tend to cause no environmental damage and can be considered perfectly safe for the environment. The small hydropower market (up to hydropower plants of maximum power equal to $10 \mathrm{MW}$ ) was estimated to be 2.6 billion of US\$ in year 2019, and according to projections it will reach 3 billion US\$ by year 2024 [1]. Although the technology used for the production of electric energy in hydropower plants is already well known and established, nevertheless there is always a need for technological improvements and the changes in the sizing methodology, especially in the operational work of mini and micro hydropower plants. In accordance with worldwide parole "act locally-think globally", small-scale hydropower plants provide clean and available electric energy, especially in isolated and remote areas, where water streams are available. Also, micro and mini hydropower plants are nature-friendly, cheaper in comparison to large hydro power plants, and can be installed at almost any water course.

Small rivers and water coursers, with their changeable velocities and torrential characteristics, can pose a challenge when planning for an installation of mini or micro hydropower plants. Research of such issues has important role in improvement of the efficiency of micro and mini hydropower plants. Appropriate understanding of all characteristics of the water courses, as well as a good anticipation of all possible situations and problems that may arise as a result of different 
climatic conditions in the system, are key prerequisites for successful design and high efficiency of small hydropower plants. Key input parameters for sizing of micro and mini hydropower plants will be provided with research and analysis of hydrological and hydrogeological properties of the rivers. One of the basic parameters for hydropower potential of rivers are daily average flows. In light of that, thorough analysis of the time series of average daily flows of water course will be carried out, not just as mentioned input parameter, but also for further elaboration of the project. Other key information for reliable analysis and sizing of the hydropower plant model is hydrogeological characterization of the medium underlying the riverbed.

There are many approaches for defining hydro-energy potential of the water courses, nevertheless the size and regime of the rivers, as well as insight into the potential and/or kinetic arrangement of the turbines are always considered as key factors. Santos et al. in [2] are using numerical modeling, i.e. computation fluid dynamics for the prediction of the flows and velocities in Amazon river. Also, authors used real measurements for validation. Research presented in [3] was based on the usage of GIS in the model which takes into the account variables that are decision making criteria, all in form of an open source tool. Methodology for determining of the river energy potential presented in [4] has been employed by SWAT (Soil and Water Assessment Tool) model, satellite data and GIS tools.

It is well known fact that (in general) more complicated and longer time modeling and field measurement gives more reliable insight for the future projects of hydropower plants, regardless of their size. There are even simple methods for such analysis, like procedure explained in [5], where analysis of the obtaining values is made in form of a comparison. Such approach gives "first hand" insight into hydropower potential, but there is a need for quite wider projection and analysis. This is a motivation for presentation of a new method for the analysis of a hydro-energy potential of the rivers, which will not entail complex modeling and/or calculation, but neither unreliable nor simplified procedures which will give useless results.

\section{Methodology}

Presented procedure for defining of the hydro-energy potential of the rivers consists of two parts. First part is Rescaled Adjusted Partial Sums (RAPS) method, while the second part is hydrogeological analysis of the analyzed location, in order to obtain the comprehensive view of the topic.

RAPS is a well-known method based on a visual determination of a subseries from original (given) series of data. By using the average value and standard deviations of the observed time series, RAPS values provide insight into the parts, where occurrence of the trends, data grouping, fluctuations and similar appearances during the time:

$$
R A P S_{k}=\sum_{t=1}^{k} \frac{Y_{t}-\bar{Y}}{S_{y}}
$$

where $\mathrm{Yt}$ is value of the analyzed member (parameter) of the considered time serie, $\mathrm{Y}$ is average value of the considered time serie, Sy is standard deviation of the considered time serie; $\mathrm{n}$ is number of members of the considered time serie, and $k=1,2, \ldots, n$ is counter during summation.

RAPS method was mostly used for hydrological analysis of the river flow [6], but it also has a wide range of an application in all research areas. For example, in analysis of the precipitation [7], water temperatures [8], meteorological parameters for the purpose of irrigation [9] and clay excavation, as well as for the waste water quality analysis [10].

Methodology presented in the paper gives reliable projection of the hydro-energy potential of analyzed locations, which could be very useful for investors, as well as for the designers of hydro power plants.

\section{Case study}


Three rivers located in different parts of Croatia were selected as the objects of presented analysis. These are Bednja, Gornja Dobra and Mirna, Figure 1 [11]. Hydrological (limnigraph) stations where time series of the average daily flow were taken are Ludbreg (Bednja), Turkovići (Gornja Dobra) and Motovun (Mirna).

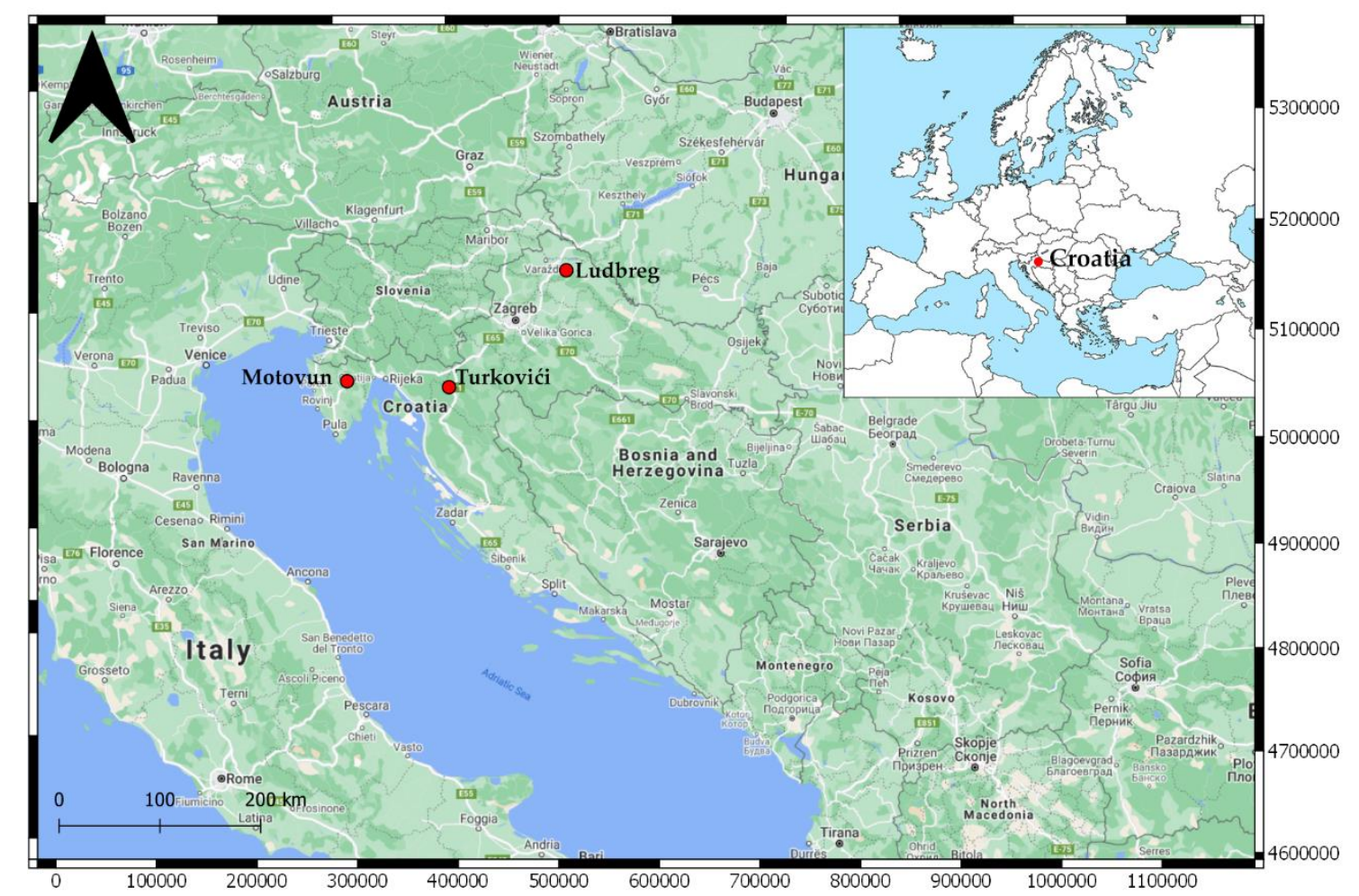

Figure 1. Locations of the analyze rivers and hydrological measuring stations.

Each of the rivers flows through different geological, i.e. hydrogeological media, which definitely has an impact on the hydrological characteristics of the observed rivers. Bednja flows through the intergranular media, Gornja Dobra through karst, while Mirna flows through the flysch (marl) media. This consequently has an impact on the hydro-energy potential of the rivers.

\section{Results and Discussion}

Figures 2-7 show hydrograms and RAPS diagrams for the flows measured at the measuring stations on the rivers Bednja, Gornja Dobra and Mirna for analysed period of 20 years, from 1999 to the 2018. [12]. General conclusion is that all three rivers have torrential characteristics, which could be seen from the hydrograms. Pronounced peaks are one of the indicators of the mentioned. Precipitation causes a very fast rising of the hydrograms after minimum one day after the precipitation ends, and very short lag of the alighting. Also, during summer periods, i.e. middle of each observed year, in most of the cases it could be concluded that flows are the smallest in comparison to the entire year. Also, years with smallest flows, 2011 and 2012, are common for all analyzed rivers.

Table 1 show average values, standard deviations, minimum and maximum values of the average daily flow of the analyzed rivers during observed period of 20 years.

Table 1. Statistical parameters of the average daily flows for river Bednja, Gornja Dobra and Mirna.

\begin{tabular}{ccccc}
\hline River & Average $\left(\mathbf{m}^{3} / \mathbf{s}\right)$ & Standard deviation $\left(\mathbf{m}^{3} / \mathbf{s}\right)$ & Minimum $\left(\mathbf{m}^{3} / \mathbf{s}\right)$ & Maximum $\left(\mathbf{m}^{3} / \mathbf{s}\right)$ \\
\hline Bednja & 6,171 & 9,980 & 0,431 & 116,000 \\
Gornja Dobra & 11,727 & 15,414 & 0,627 & 171,000 \\
Mirna & 5,559 & 9,909 & 0,061 & 89,800 \\
\hline
\end{tabular}




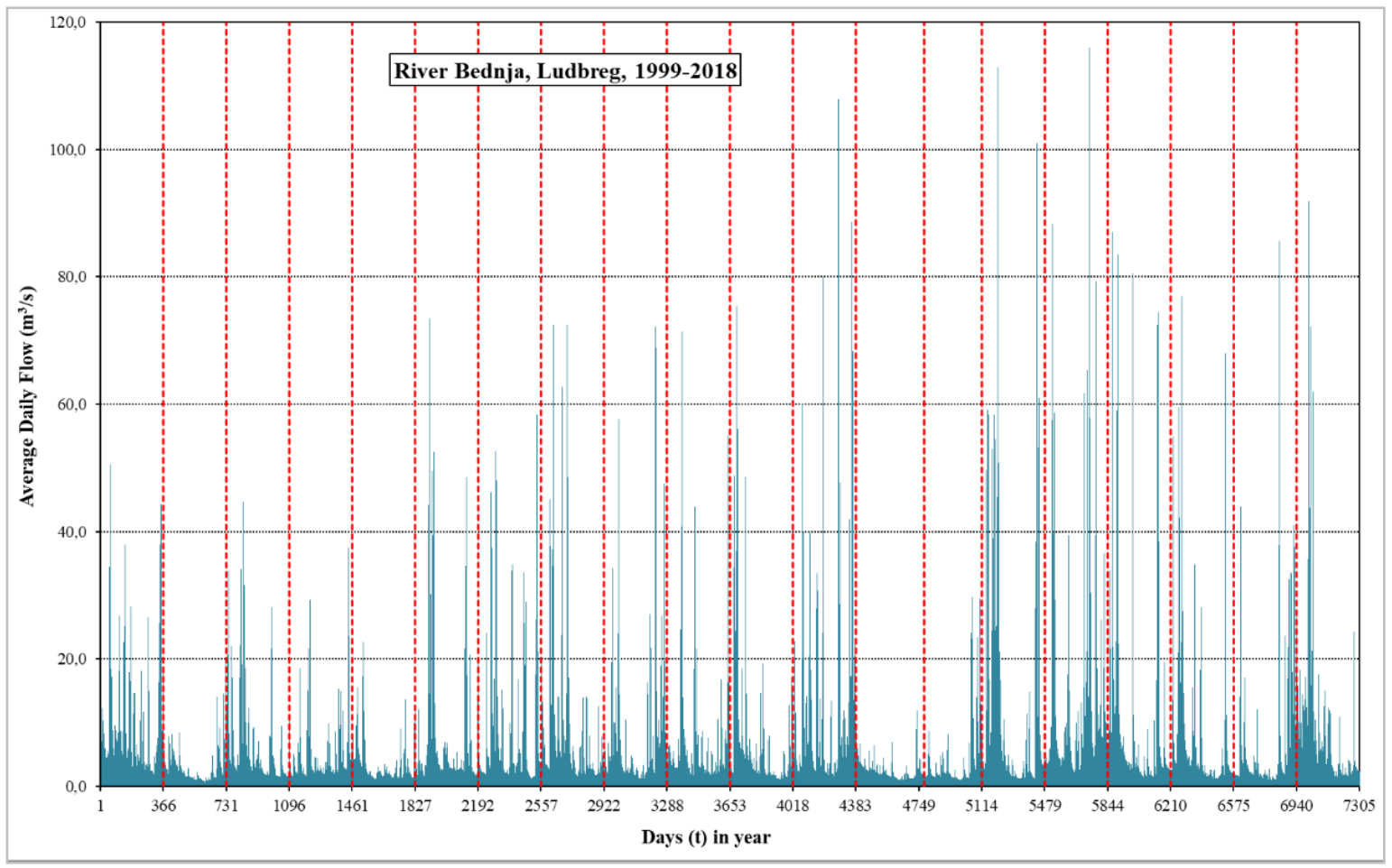

Figure 2. Average daily flow of river Bednja, 2020.

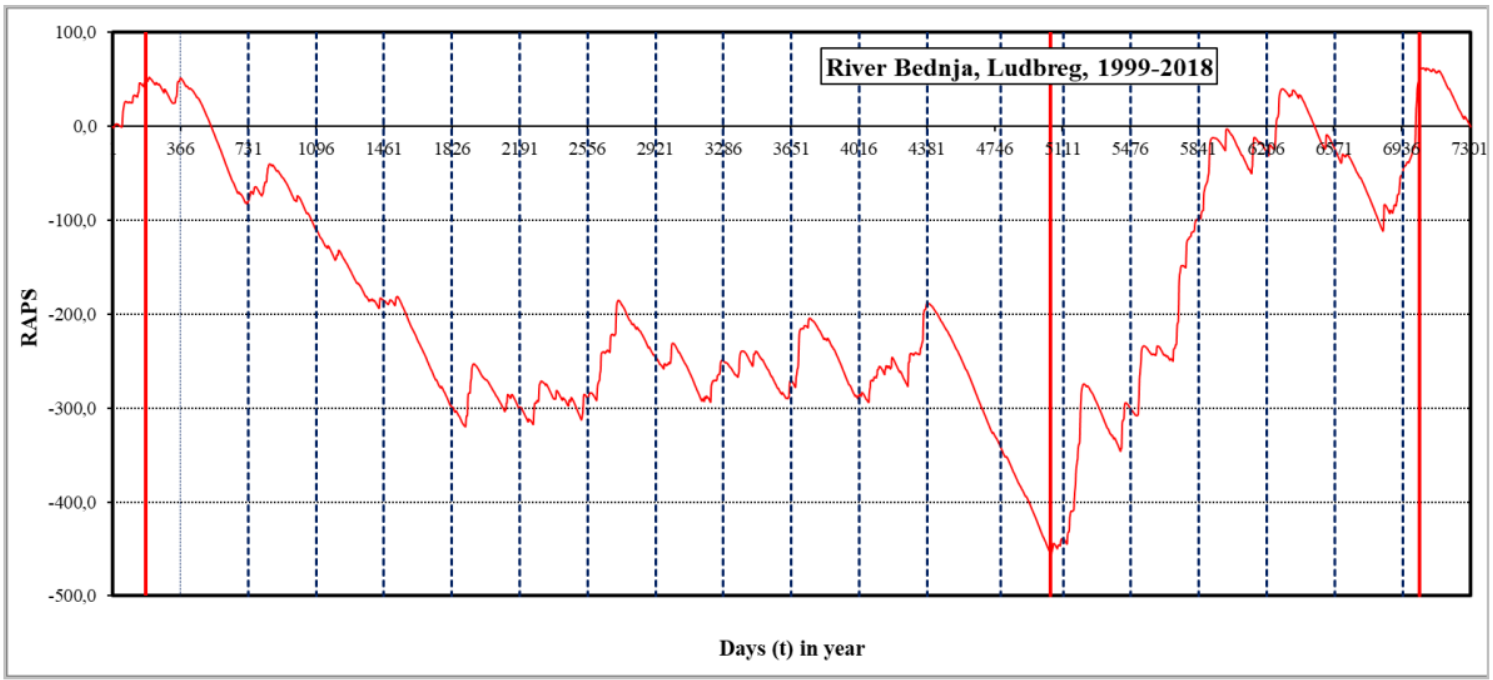

Figure 3. RAPS diagram for the river Bednja.

Analysis of the RAPS diagram for the river Bednja establishes four subperiods. First one is from middle of 1999 year, second from middle of 1999 year till end of 2012 year, third from end of 2012 year till beginning of 2018 year, and last one from beginning of the 2018 year and extends further (fourth subserie). Second subperiod divides period of the conditionally speaking "low flows" compared with third subperiod with "high flows" years. 


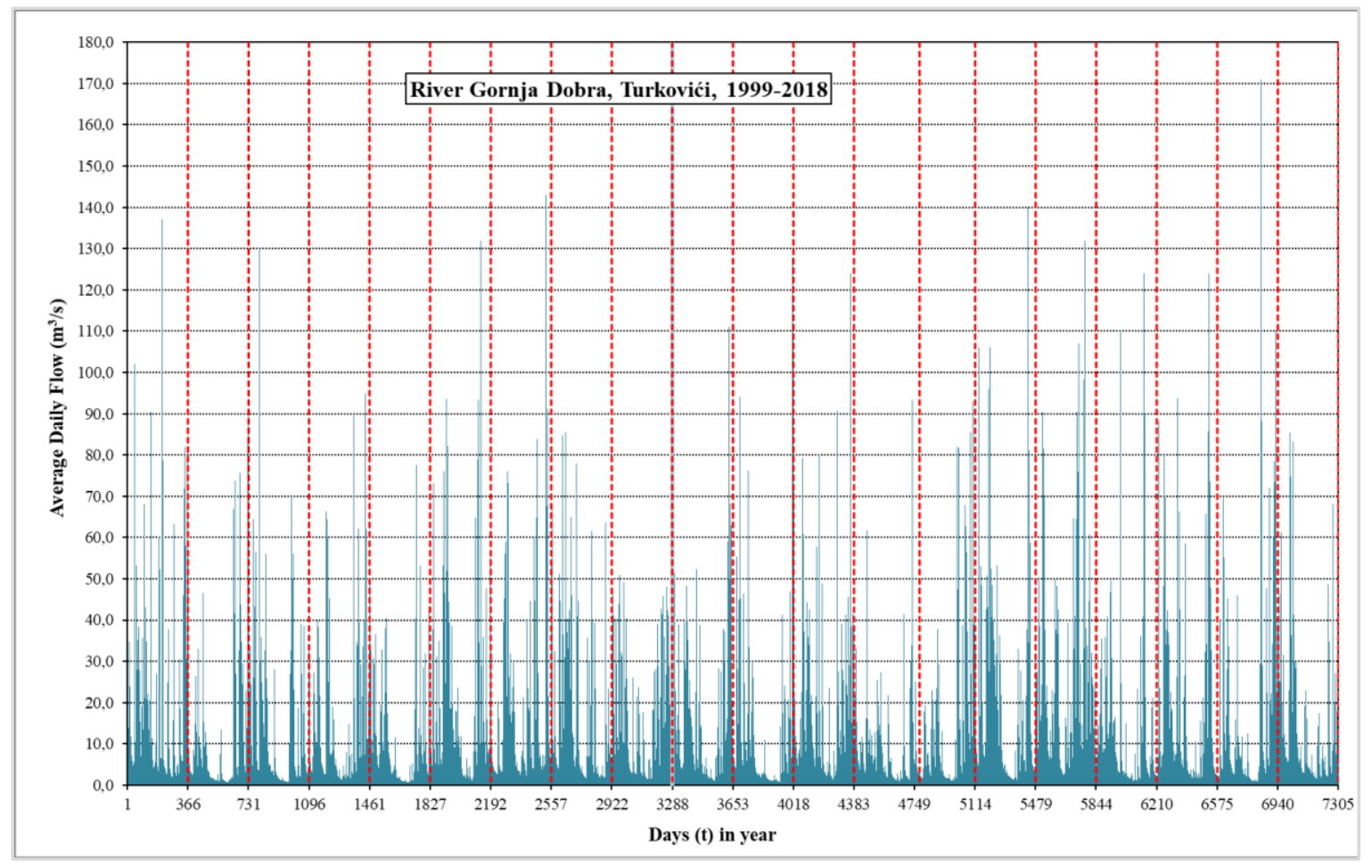

Figure 4. Average daily flow for the river Gornja Dobra, 2020.

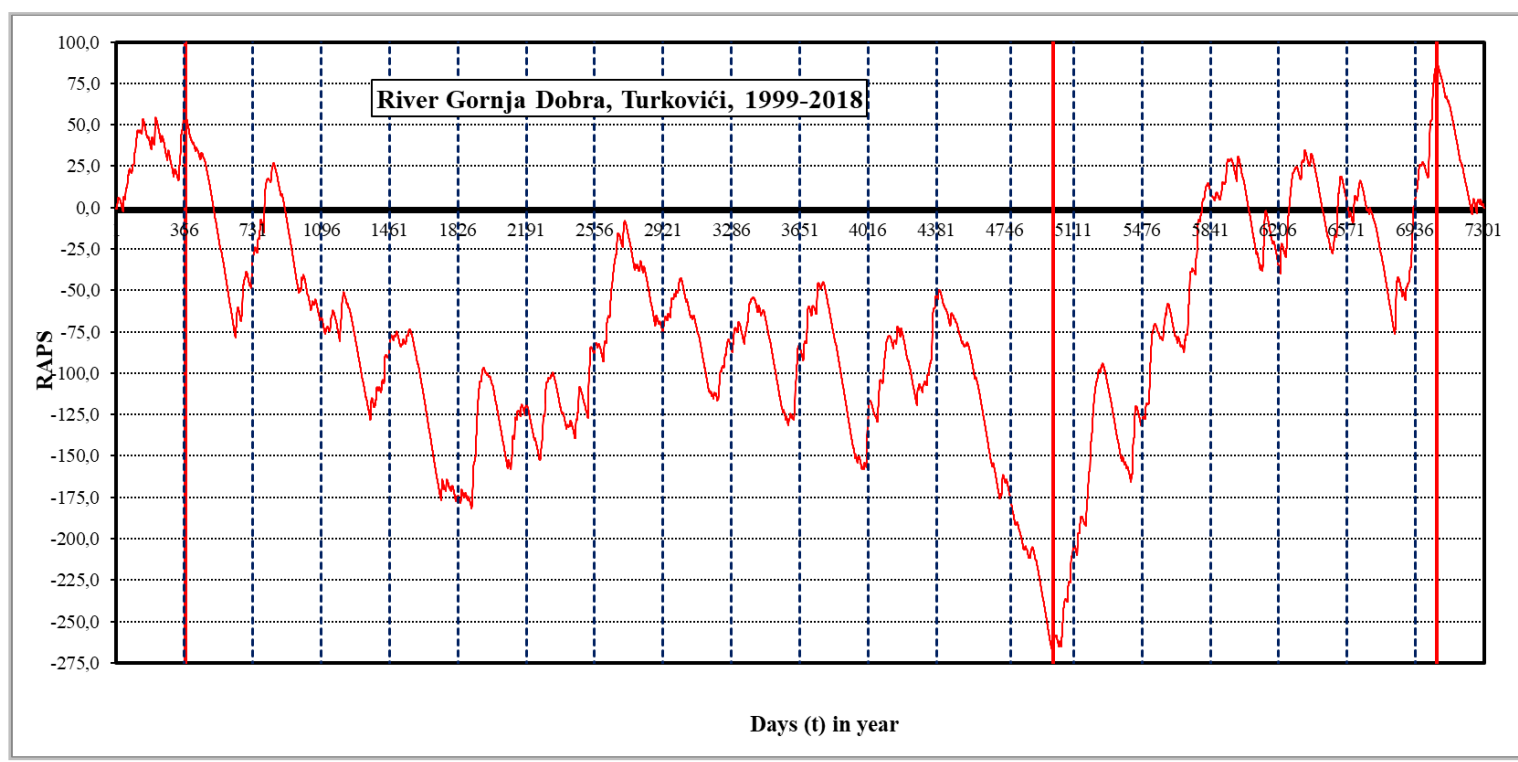

Figure 5. RAPS diagram for the river Gornja Dobra.

Figure 5 shows a bigger number of the subseries. Analysis of the RAPS diagram for the river Gornja Dobra asserts four subperiods. First one is until the end of 1999 year, second from end of 1999 till end of 2012, third from end of 2012 till beginning of 2018, and last one from beginning of the 2018 year and extends further. RAPS diagrams for Gornja Dobra and Bednja also shows four subseries as Bednja, but there are no complete overlapping. Joint parts are beginning of the subdivision during years 1999 and 2018. This implies on the regional climate change. Other subdivisions are not so easy for explain. Such could be a consequence of a regulation work on the rivers, or maybe local climate changes, which are particular for the analyzed area(s). 


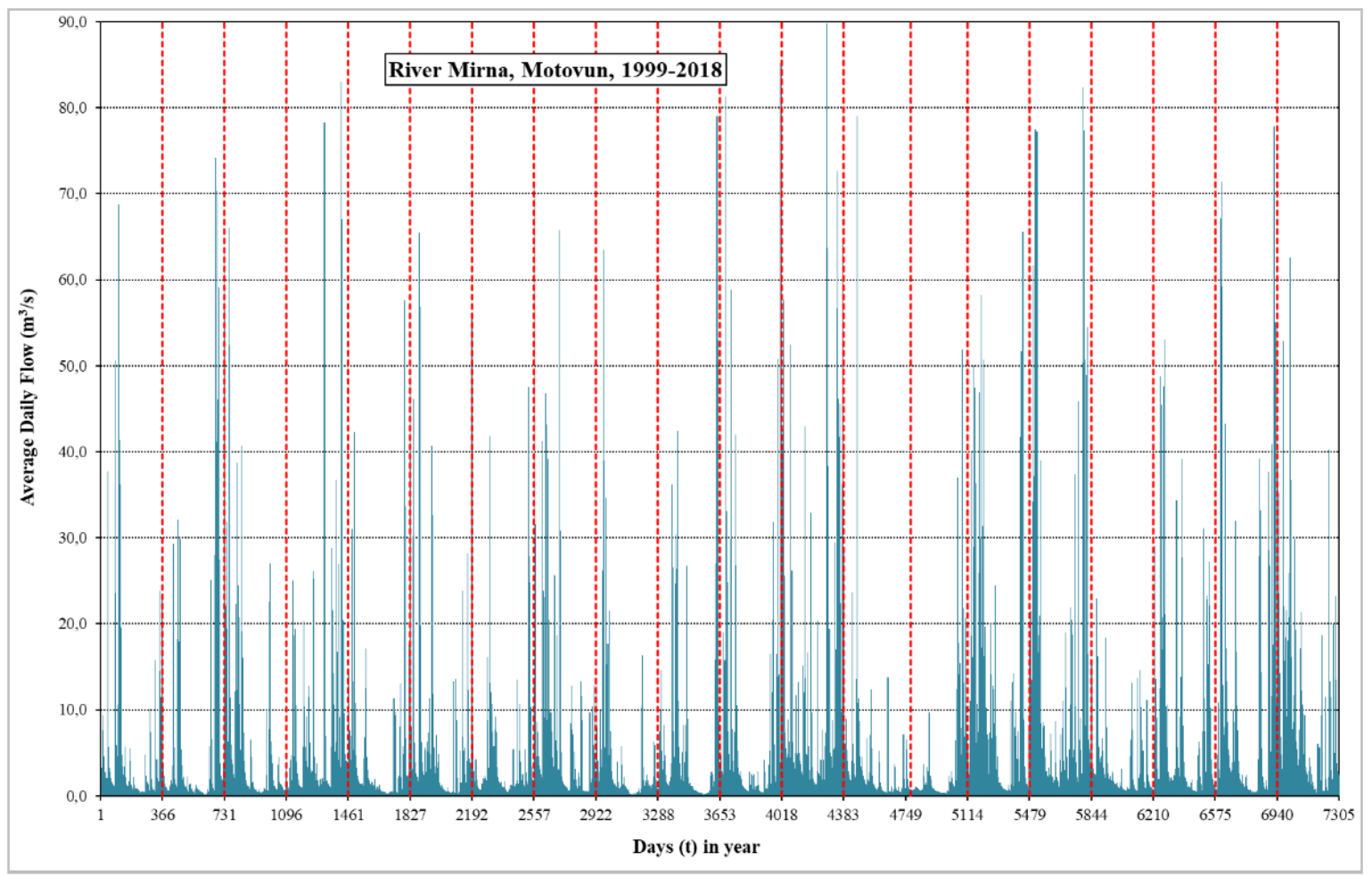

Figure 6. Average daily flow for the river Mirna, 2020.

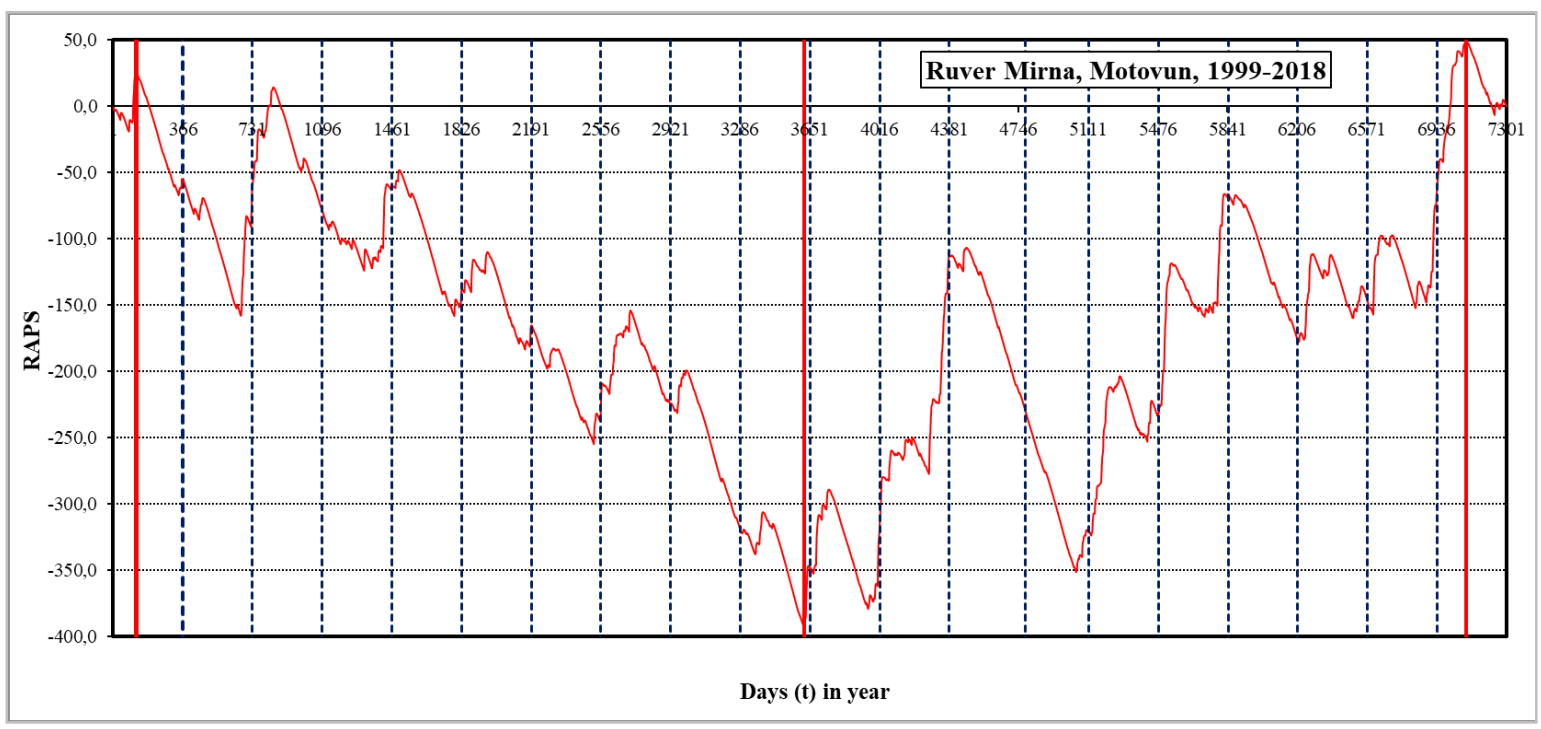

Figure 7. RAPS diagram for the river Mirna.

For river Mirna, analysis of the RAPS also asserts four subperiods. First one is from beginning of 1999 year, second from beginning of 1999 year till end of 2008 year, third from end of 2008 year till beginning of 2018 year, and last one from beginning of the 2018 year and extends further.

Regarding hydro-energy potential, such analysis indicates that in case of occurrence of the subseries within original time serie of the flow, attention should be focused on these parts of the analyzed time periods. Specifically, in analyzed cases, periods from year 2018 are interested because there are present irregularities, which affect average daily flow series. Calculation of the flow required for sizing of the hydropower plants should be focused on those values in such subseries. This surely depends about duration of the available time series (10, 20 or longer), because RAPS calculation will not show same division of the given time serie. That is the object of the further 
analysis, which will not be presented in this paper regarding the purpose and length of the paper, but definitely will be presented in the extension of the paper.

Figure 8 shows surrounding at the measuring station Ludbreg on river Bednja, Figure 9. shows measuring station Turkovići on river Gornja Dobra, while Figure 10 shows surrounding on measuring station Motovun at river Mirna [13].

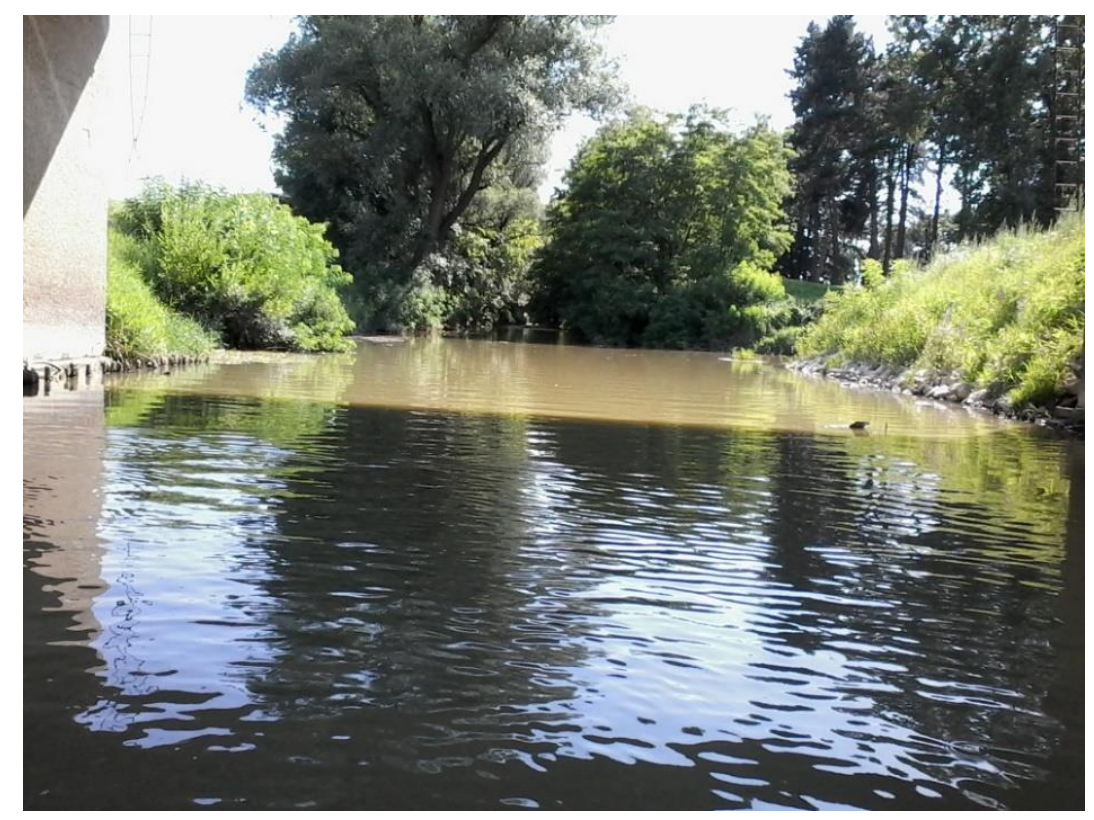

Figure 8. View at the measuring station Ludbreg on river Bednja.

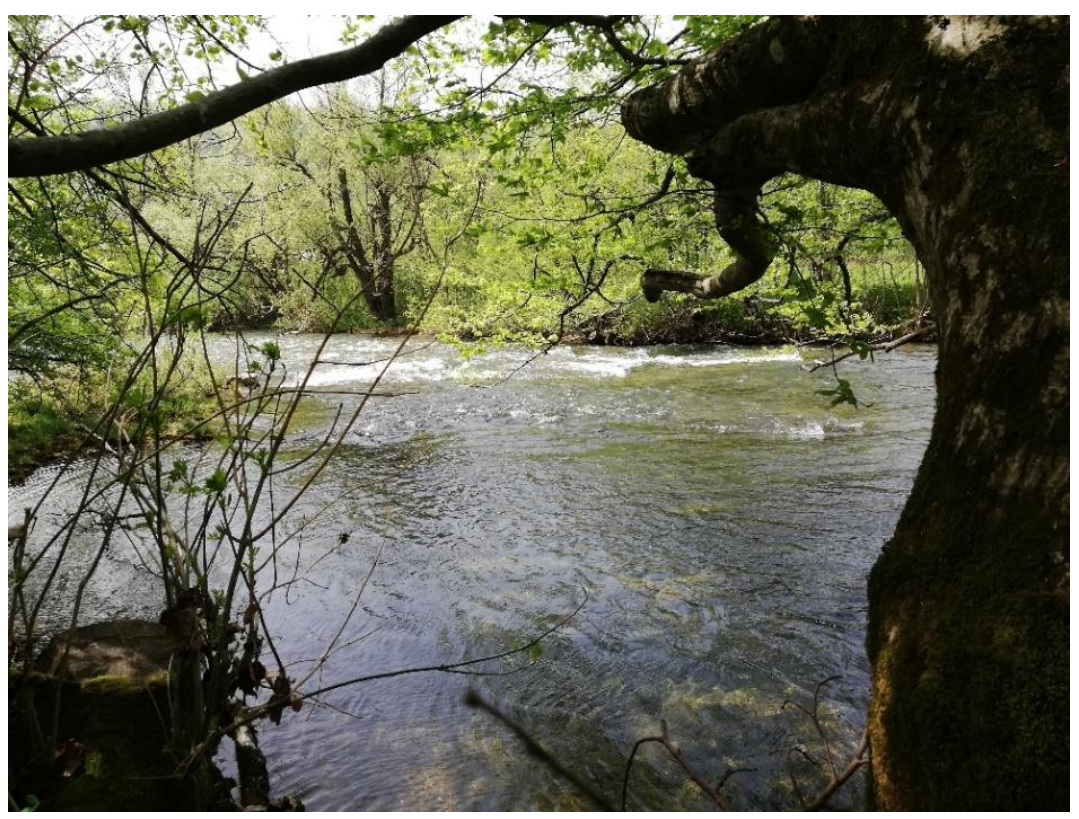

Figure 9. View at the measuring station Turkovići on river Gornja Dobra. 


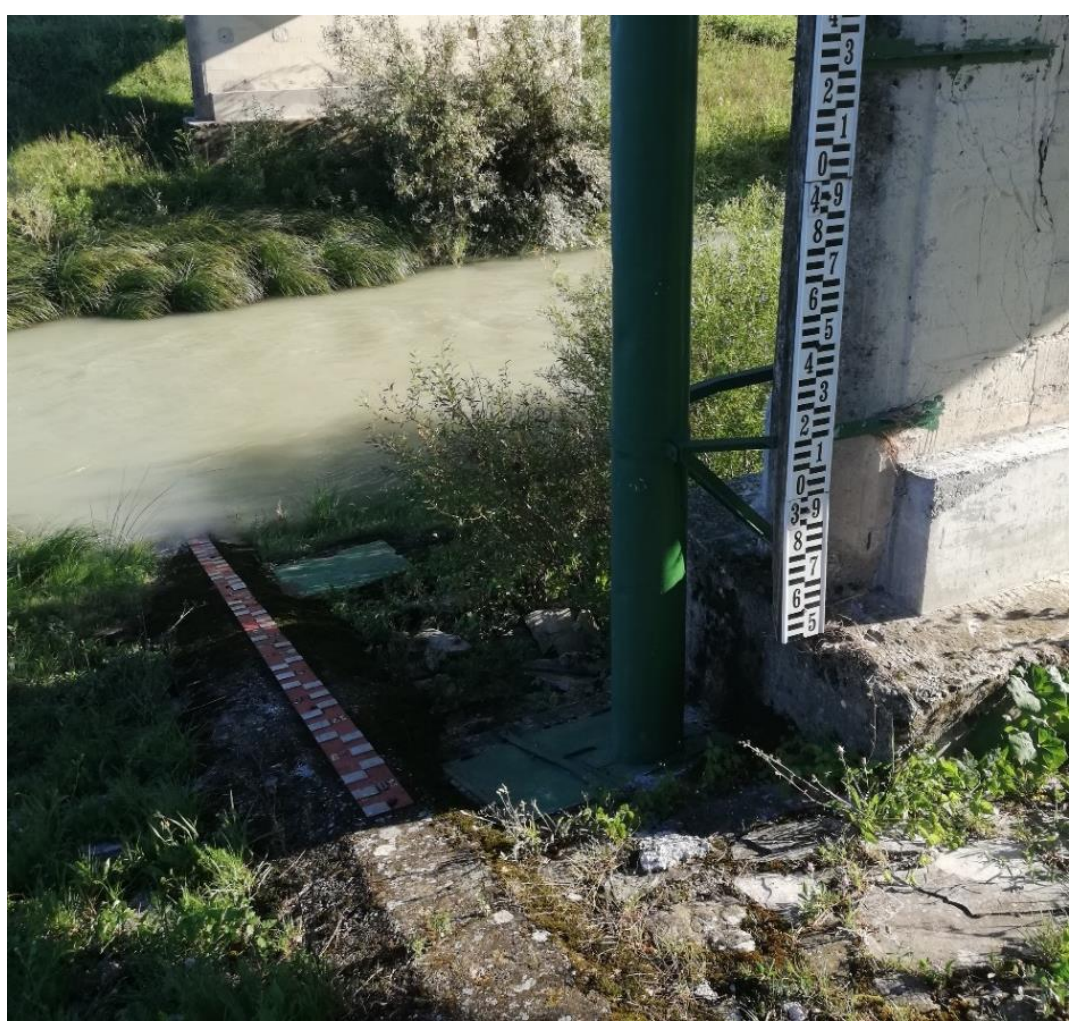

Figure 10. View at the measuring station Motovun on river Mirna.

From Table 1, it could be seen that River Gornja Dobra has biggest deviation of the averaged daily flow, compared with the Bednja and Mirna. It can be explained by the characteristics of the river bed. Gornja Dobra emerges near Skrad, in the area comprised of Palaeozoic clastites. After that, the river flows over the Jurassic limestones and dolomites of the Ogulin-Oštarije karst platform. During its flow through the dolomites, flow losses are small due to the lack of caverns and sinkholes which are characteristic feature of the limestones [14]. Dolomites are mostly impermeable and in the karst they represent a barrier to the passage of water.

\section{Conclusion}

Presented methodology has shown the regime of the water flow by application the RAPS analysis of the average daily flow series, together with review of the hydrogeological characteristics. All analyzed rivers have potential for building of the small hydropower plants. Detailed analysis, i.e. extension of the research in first step will include analysis of the other measuring stations on the analyzed rivers and establishing of the functional connections between flows measured on several measuring stations. Next step are field measurement and prospection on the potential locations, where installation of the hydropower plants is possible, and where data does not exist, everything with regards on the hydrogeological properties. Numerical analysis should include RAPS analysis of the precipitation time series, as well as of each particular time serie of the average daily flow in order to obtain complete picture of the analyzed area.

Author Contributions: B.Đ. and L.P. conceived and designed the experiments; B.Đ. and L.P. performed the experiments; D.D. and B.Đ. analyzed the data; L.P, D.D. and N.K. contributed analysis tools; B.Đ. and D.D. wrote the paper.

Conflicts of Interest: The authors declare no conflict of interest.

\section{Abbreviations}

The following abbreviations are used in this manuscript: 
RAPS: Rescaled Adjusted Partial Sums

SWAT: Soil and Water Assessment Tool

GIS: Geographic Information System

\section{References}

1. Qaranta, E. HYDROPOWER, Hydropower development and sustainability project, The Next Frontier, 2020. Available: https://www.researchgate.net/HYDROPOWER, Accessed: 7. October 2020.

2. Santos, I.F.S., Camacho, R.G.R., Fiho, G.L.T., Botan, A.C.B., Vinent, B.A. Energy potential and economic analysis of hydrokinetic turbines implementation in rivers: An approach using numerical predictions (CFD) and experimental data, Renewable Energy 2019, 143, 648-662. DOI: 10.1016/j.renene.2019.05.018, Available: https://ideas.repec.org/a/eee/renene/v143y2019icp648-662.html, Accessed: 7. October 2020.

3. Garegnani, G., Sacchelli, S., Balest, J., Zambelli, P. GIS-based approach for assessing the energy potential and the financial feasibility of run-off-river hydro-power in Alpine valleys, Applied Energy, 2018, 216, 709-723. Available: https://doi.org/10.1016/j.apenergy.2018.02.043, Accessed: 7. October 2020.

4. Pandey, A., Lalrempuia, D., Jain, S.K., Assessment of hydropower potential using spatial technology and SWAT modelling in the Mat River, southern Mizoram, India, Hydrological Sciences Journal, 2013, 60, 1651-1665. Available: https://doi.org/10.1080/02626667.2014.943669, Accessed: 10. October 2020.

5. Kalnacs, A., Kalnacs, J., Mutule, A., Persis, U. Methods for Estimation of the Riverflow Potential for Hydrokinetic Power Generation, Latvian Journal of Physics and Technical Sciences, 2014, 51. Available: https://doi.org/10.2478/lpts-2014-0008, Accessed: 10. October 2020.

6. Bonacci, O., Andrić, I. Sinking karst rivers hydrology - case of the Lika and Gacka (Croatia), Acta Carsologica, 2008, 37(2-3), 185-196. DOI: 10.3986/ac.v37i2.146 Available: https://www.researchgate.net/publication/285704502_Sinking_karst_rivers_hydrology_Case_of_the_lika_ and_gacka_Croatia, Accessed: 10. October 2020.

7. Garbrecht, J., Fernandez, G.P. Visualization of Trends and Fluctuations in Climatic Records, Journal of the American Eater Resources Association, 1994, 30, 297-306. Available: https://onlinelibrary.wiley.com/doi/abs/10.1111/j.1752-1688.1994.tb03292.x, Accessed: 12. October 2020.

8. Basarin, B., Lukic, T., Pavic, D., Wilby, R. Trends and multi-annual variability of water temperatures in the river Danube, Serbia, Hydrological Processes 2016, 30, 3315 - 3329 . Available: https://doi.org/10.1002/hyp.10863, Accessed: 12. October 2020.

9. Težak, D., Soldo, B., Đurin, B., Kranjčić, N. Impact of Seasonal Changes of Precipitation and Air Temperature on Clay Excavation, Sustainability, 2019, 11(22), 6368. Available: https://doi.org/10.3390/su11226368, Accessed: 12. October 2020.

10. Đurin, B., Priček Siročić, A., Muhar, A. Analiza povezanosti pokazatelja kakvoće otpadne vode s temperaturom i oborinama pomoću RAPS metode, 2017, Hrvatske vode, 25, 247-252. Available: file://C:/Users/Korisnik/Downloads/HV_102_2017_247_252_Durin_et_al\%20(1).pdf, Accessed: 12. October 2020

11. Google maps, Available: https://www.google.com/maps-croatia, Accessed: 1. November 2020

12. Croatian Meteorological and Hydrological Service (CMHS). Daily flow for Ludbreg, Turkovići and Motovun from 1999 till 2018; Croatian Meteorological and Hydrological Service (CMHS): Zagreb, Croatia, 2020.

13. Photo by Bojan Đurin, 2018-2020.

14. Bonacci O., Andrić I. (2010) Hidrološka analiza krške rijeke Dobre. Prethodno priopćenje, Hrvatske vode, $18 / 72$, 127-138. Available: https://www.voda.hr/sites/default/files/pdf_clanka/hv_72_2010_127-138_bonacci-andric.pdf, Accessed: 1. November 2020.

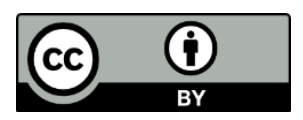

(C) 2020 by the authors. Submitted for possible open access publication under the terms and conditions of the Creative Commons Attribution (CC BY) license (http://creativecommons.org/licenses/by/4.0/). 